Unity Journal

Vol. III, 97-108, 2022

Doi: https://doi.org/10.3126/unityj.v3i01.43318

Prithvi Narayan Shah Research Center

Directorate General of Military Training, Nepali Army

Kathmandu, Nepal

\title{
North South Connectivity: Opportunities and Challenges in National Security and Development
}

\section{Sabin Koirala}

\begin{abstract}
After the decade long civil conflict, Nepal has been moving through a transitional phase for the development and prosperity. Comparing to other landlocked states, the indicators depict low level of infrastructure development. Being landlocked and a mountainous country, Nepal has high trading cost due to difficult geography and lack of reliable infrastructures, decreasing competitiveness domestically and internationally. North South connectivity not only connects China and India but also revives the role of Nepal as land linked. Nepal is always trying to boost economic growth using liberalization, decentralization policy and has now transformed from unitary state to federal state. The growing expectation of people towards prosperity and development has driven the state to make investment on large scale connectivity projects in transport, energy, aviation, communication sector. Having resource constraints, state should mobilize the scarce resources in rational and optimum ways to maximize the development opportunities and mitigate the security challenges and threats. Furthermore, it is necessary to assess both long term and short-term impact during strategic project formulation. This paper aims to identify opportunities and challenges of cross border connectivity in national
\end{abstract}

security and development using various information and facts through secondary sources and with examples of other nations sharing similar attributes. Findings suggest that Nepal should develop multimodal connectivity strategies while considering strategic location of Nepal and should utilize international assistance and support while maintaining the relationship with neighbors, regional power and great power based on sovereign equality, mutual respect, and benefits. Further, this study contributes to policy makers and planners for the appraisal of strategically important projects.

Keywords: Development, Cross country Connectivity, National Security, Nepal

\section{Introduction}

Nepal is rectangular shaped country, sandwiched between two powerful economies in Asia, such as India and China. Both the countries have huge population around 2.5 billion people. Nepal is mountainous and landlocked country having less competitiveness domestically and internationally, mainly due to connectivity issues. Connectivity problems on northern border with China are related to high altitude mountains and difficult weather and topography. Nine points of connectivity with Tibet has been identified, of which only 
several are technically and economically feasible. The southern border is quite porous and permeable with large number of informal trades. 15 mutually agreed entry and exit points has been identified, out of which seven are operational.

Planned development model was started in Nepal in 1956 AD with the establishment of democracy. The state transformed from autocratic governance system to democratic system and from centralized system to federal system. With the reestablishment of democracy in 1991, state policies changed from interventionist, state led policy to liberalization, privatization and globalization for the rapid economic growth and prosperity. North South and East west connectivity projects in transportation, energy and communication sector were appraised with the establishment of democracy and periodic plans. Although government efforts were towards attracting private sector for the financing and construction of large infrastructure project, the participation of private parties for investment in those projects are limited. Different sectoral policies like trade and industrial policies, transport sector policies, energy sector policies, infrastructure financing policies were formulated. Trade and industrial policies intend to improve market accessibility and builds domestic support institutions for exporters and enhance the capacity and competency of government to coordinate trade related institutions and development partners. Transport related policies recognize the need to connect domestically and internationally with the connectivity of reliable and safe all-weather roads. Air transport is mainly focused on tourism enhancement and access to mountainous districts. Similarly, concept of rail for domestic and international connectivity is currently under discussion in Nepal. Energy sector policies are intended for generation of electric energy in huge amount and transmit electricity within country and trans-border for export and thus decrease the trade deficit. With the recognition of private sector in infrastructure development, institutional arrangement and formulation of private sector friendly policies and laws are enacted in Nepal. Boot act, public private partnership and investment act, foreign investment and technology transfer act are formulated, and Nepal investment board has been established for the coordination and management of large projects.

Nepal is suffering from deficient and poor cross-border infrastructure. Except India, only $0.8 \%$ of Nepal's total trade is with the SAARC (South Asian Association for Regional Cooperation) and South Asia Subregional Economic Cooperation (SASEC). Nepal signed subregional motor vehicle agreement with Bangladesh, Bhutan and India in 2015 to improve transport efficiency and facilitate trade by increasing cross border movements of goods \& vehicles. SAARC and SASEC has been supporting these four countries with an aim to reduced transport cost and improve regional connectivity (ADB, 2019).

\section{North South Connectivity}

Nepal's participation in BRI in 2017, has established a framework of trans-Himalayan multi-dimensional connectivity network of trade, energy, transport (Singh, 2019). The extension of Qinghai-Tibet railways from Lhasa-Sighatse $(253 \mathrm{~km})$ which is located at near proximity from Nepal was completed in 2014. China has agreed to extend $72 \mathrm{~km}$ railway from Sighatse to Kathmandu and

1 BRI- Belt and Road Initiative is a global infrastructure development strategy adopted by Chinese government. 
connect Pokhara and Kathmandu. The railway which links Sighatse-Kerung-Kathmandu is considered as game changing project of Nepal for economic prosperity. India has proposed to construct Raxaul-Kathmandu and east west railway (Kakarvitta-Gaddachauki), parallel to east-west highway. Thus, the overall distance between Sighatse to Kathmandu and from Kathmandu to Raxaul will be around $300 \mathrm{~km}$, linking two big economies using land territory. The present dependency of Sino-India trade using around $5000 \mathrm{~km}$ of water, rail and road transport can be replaced by using shortest route. This connectivity can change the paradigm of Nepal, thus increasing the economic potential (Baniya, 2020).

Some of the recently completed and ongoing regional cooperation and integration projects in Nepal are: (Rana \& B, 2014)

a. Nepal Multimodal Transit and Trade Facilitation Project, which focused on constructing inland container Depots (ICD) at three locations along the Indian border.

b. Syaphrubusi-Rasuwagadhi Road project and the Galchi-Trisuli-DhuncheSypharbesi road under road connectivity sector project connected Rasuwa to Kerung in Tibet and Galchi-TrisuliDhunche-Syphrubesi road provides the second alternative road connecting China with India.

c. BP Koirala highway project connects the Capital city of Kathmandu with the Eastern Terai and link them to neighboring cities in India.

d. Airport enhancement project has been upgrading Tribhuvan International airport (TIA) and three domestic airports. e. Sub regional transport enhancement (STEP) project aims to facilitate efficient and safe transport within Nepal, with India and through India, with Bangladesh and with Bhutan.

f. SASEC Trade facilitation project aims to help three SASEC countries including Nepal, adopt an international customs administration protocol, upgrade existing automated custom management system.

g. Nepal-India electricity transmission and trade project intends to establish cross border transmission capacity of about 100 MW to facilitate electricity trade between India \& Nepal by at least 100 MW.

h. East west optical fiber cable project, which includes placing $858 \mathrm{~km}$ of optical fiber along the East-West highway.

i. SASEC information highway project seeks to develop i) SASEC regional network with fiber-optic and data interchangeably capacity ii) SASEC village network by expanding broadband information and communication technology (ICT) access iii) A SASEC research and training network to build technical and business skills in ICT.

j. Nepal India Trade and Transport facilitation project, which aims to decrease transport time and logistic costs for bilateral trade between Nepal and India an transit trade along KathmanduKolkata corridor.

\section{Conceptual Framework of Study}

The north south connectivity can be the turning point for the economic development of Nepal and prosperity. If we take an example of transportation connectivity projects, north south connectivity projects 
can change the status of country from land locked to land linked. The development of infrastructures like rail, road, cable car, waterways will have direct and indirect effect on economic growth and security issues. The connectivity can enhance international trade which increases the employment opportunities, improves the trade deficit, improves the balance of payment. Reliable and safe transport network decreases the transport user cost which reduces the per unit cost of goods and can help to control inflation in country. Furthermore, the connectivity increases accessibility to market center and economic center thus creating opportunities for employment and development of market. Similarly, transportation connectivity may have security issues due to increase in diplomatic relations, border disputes and internal \& external migration. The conceptual framework of the study is shown in following figure.

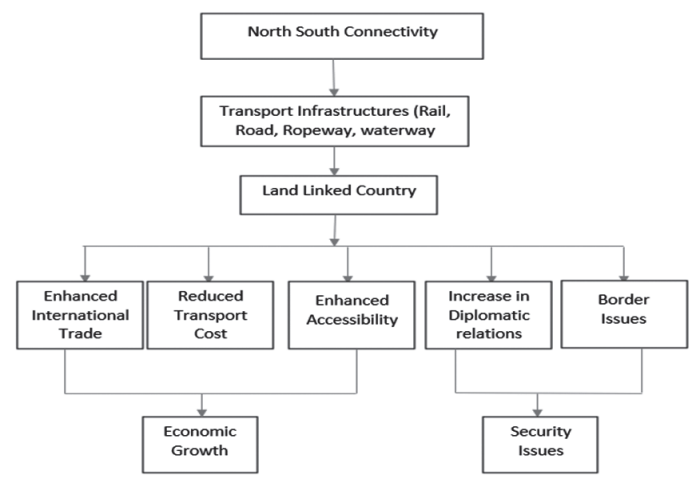

Fig: Conceptual Framework

\section{Methodology}

This research is based on qualitative strategy using secondary sources like journal articles, conference proceedings, books, government reports, newspapers, interviews, and websites. Among various sectors of connectivity like energy, transport, trade, we have considered transport sector for the study. Recorded interviews of experts in news article and TV/YouTube were first randomly selected, thoroughly studied, and analyzed and interpreted. This research used a comprehensive approach for accumulation of information and objective approach to derive the conclusion. Finally, based on content analysis of various sources and information on relevant issues, problems, analyses, conclusions, and recommendation were identified.

\section{Discussion and Analysis}

\section{Geo-Strategic Location of Nepal}

The figure below highlights that Nepal has the potential to be a land-linked between India and other South Asian countries and China. Nepal can connect with Bangladesh, northeastern part of India and China can land link between Pakistan, Afghanistan, Central Asia, South Asia and Southeast Asia. Rana (2013) has argued that in the past, Nepal had been an entrepot for India-PRC trade and a node on the historical SSR, that started in Yunan, passing from Myanmar to India and Nepal, and looping back to Tibet.

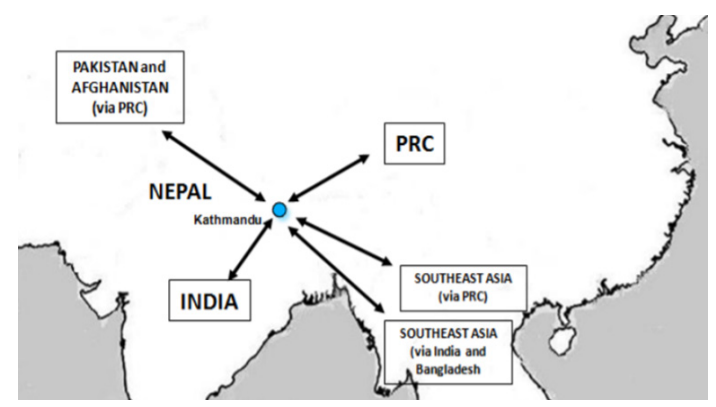

Fig: Strategic location of Nepal

Source: Author

The location of Nepal is of ladder like style on both sides physical gap between the IndoGangetic Plain in the south and Tibetan 
Plateau in North. Important aspect of Nepal land-lockedness is more acute in a sense that other land locked countries have alternate access to sea through more than one country. Moreover, Nepal's physical extrovertedness is also distinct that other landlocked countries such as Switzerland or Afghanistan have their most effective part of central heartland both in terms of productivity as well as strategically significance (Bhattarai, 2003).

Modern Nepal's founder, the late King Prithivi Narayan Shah, has remarked Nepal as a yam between two boulders. Nepal's foreign policy has remained historically on maintaining balanced relationship with its neighbors. Nepal's relation with India is deep rooted in historical, geographical, cultural, socioeconomic background. Moreover, India has played a significant role in Nepal's political changes since 1950 . However, having multidimensional relationship, the relation is bittersweet. The bilateral relationship between India \& Nepal became problematic after the 2015 economic blockade, which was actually a result of India's hegemonic assertion over Nepal's new constitution. Furthermore, after the inauguration of strategically important link road through to Lipulekh on $8^{\text {th }}$ May to trade with Tibet and for Pilgrimage to the sacred Kailash Mansarovar, Nepal published a new political map on 20 may covering the areas of Limpiyadhura, Kalapani and Lipulekh. Although these places have been historically claimed by Nepal, but it remains under India's control after the 1962 Sino-Indian war. One of the biggest factors creating prejudice for Nepal is the habit of equating China with every political action taken by Nepal. Indian Army chief General Manoj Naravane controversially suggested that Nepal had raised the border issue at the behest of China (Thapa, 2020).
The major concern of Nepal with China is the involvement of more than 20000 Tibetan refugees in anti-China activities related to the free Tibet movement. After the end of monarchy and with the establishment of republic state, Nepal's significance in the strategic calculus of China has increased. During the visit of Chinese President Xi Jinping in October 2019, he declared China would help Nepal to become land-linked state. The joint statement issued at his visit mentioned that both countries had agreed to elevate the bilateral relationship to a 'strategic partnership of cooperation featuring everlasting friendship for the development and prosperity. Till the date, every Chinese leader since Mao Zedong has reiterated that Nepal-China relations would be based on five principles of peaceful co-existence with an emphasis on non-interference in the internal affairs of Nepal. It is important that Nepal will have to ensure its foreign policy to serve its national interest in a complex geopolitical environment. Nepal's path to peace and prosperity will be best served if it maintains a cooperative relationship with neighbors. The historical and unwavering faith in the principles of non-alignment serves as a beacon in its desire to seek amity with all and enmity with none (Thapa, 2020). The Himalayan frontiers between India and China remain contentious as showcased by the border clashes in Ladakh and the Doklam plateau crisis. Increased Chinese influence in Nepal would add tensions to the already contentious Sino-Indian relations.

\section{Connectivity and Economic Aspect}

North South Corridor connecting mid hill highway acts as major key to economic growth and development in mid-hill. Farmers inTerai area like Nepalgunj or Birgunj cannot grow apples, like in mid hills, and many 
seasonal vegetables grow better uphill. In Jumla, tons of apples are left to rot every year until the connectivity was developed. But now the corridor has allowed farmers to sell their fruit to market. The consumption of Nepalese fruit in market substitutes the fruit from India, thus reducing trade deficit in these sector (Andersen, 2015). The main source of household income in rural Nepal is agricultural sector. On road corridors in hilly regions, entrepreneurial enterprise has been doubled with the rampant increment in number of shops, tea rooms and workshops, mainly by Janjati people. Some retail outlet became wholesalers with the transformation from traditional periodic market to well established market (Paul, Ansu, \& Sharma, 2013). The rail transport has a potential advantage over roads because of higher speed, shorter border crossing and few route delays. However, the extent to which this potential can be realized is subject to debate (Arvis, Raballand, \& Marteau, 2011).

Transport network fosters linkage between major urban centers and relatively backward rural areas, which generates the potential for development along the corridor and for exploiting economics of scale, thus providing for industrial agglomeration along the corridor. Result suggests that there is a positive correlation between improved quality of infrastructure and economic growth, and improved connectivity enables countries to join the global value chain (ADB, 2017). Using the IDE-GSM model Kumagai \& Isono (2011) found that firms became able to buy and sell at a better price due to lower transport cost, contributing to better economic growth. Physical connectivity needs to be supplemented by better institutional policies, including streamlining of procedure and use of technology. Improved connectivity boosts regional production network encouraging new economic activities and employment creation. Enhanced network reduces trade cost, raising country's competitive and comparative advantage and trade flow, thus leading to better accessibility, low poverty level and raise human welfare and quality of life.

The regional allocation of economic impact in Nepal is concentrated in capital city Kathmandu and along the southern border with India. This is because of connectivity available due to international airport in Kathmandu and east-west highway in south. According to IDE-GSM simulation results, positive impact in Kathmandu and the southern border region is mostly driven by the service sector. Other manufacturing and agricultural sector have gained minimal benefit, while the food processing sector suffered from negative impact. Similarly, the simulation result showed that economic impact is concentrated in Kathmandu and in the eastern part of Nepal. The result corresponds to assumption that the connectivity of Nepal has been improved due to direct railway service from Birgunj, which is major border point and inland waterway along the Koshi river (Hayashi, et al., 2020). This paper estimated the economic impact on ongoing projects in Nepal and the proposed development of alternate connectivity with India and have confirmed the substantial economic benefits gained from connectivity projects. Economic benefit is also projected from the proposed railway and inland water connection with India. Following the location of existing project, impact is concentrated in Kathmandu and east Nepal. It is then expected that new connectivity project cause major shift in the mode of trade. While the railway will gain about half of the trade with 
India before the inland waterway, the share of railway will drop to a third once the inland waterway starts the operation.

\section{Connectivity and Migration}

Research shows mixed result about connectivity and migration. The wellestablished road/transport connectivity increases the economic opportunities in rural area and decreases the necessity of migration in search of job (IOM, 2019). However, some article believes that with the increase in accessibility of people to urban areas, the rate of migration gets triggered (Tsang \& Rohr, 2011). The development in the form of a regionaleconomicentity enhancesopportunity for engagement and provides easy solutions for the problems related to insurgency and illegal migration. People to people contact for enhancing ethnic \& cultural association with neighboring countries provide benefits to the country (IPCS, n.d.). The economic impact of improved connectivity works through agglomeration effect and rises in trade and migration. Over the long term, connectivity alters the economic structure generating income, consumption demand, new jobs and gender equity which are viewed as wider economic benefits (ADB, UKAID, JICA and WB, 2018). Enhanced connectivity enables economic entities to acquire new ideas and knowledge from other economic centers and raising productivity and generating competitive advantages. Warr et al. (2009) studied the economic impact of improved infrastructure facilities using general equilibrium model based on input output structure and found both the long term and short-term effects. They concluded that the benefits over the long run as new investment come in and the labor force migrates to another region for better jobs and higher wages.

\section{Connectivity and National Security}

Due to geo-strategic location of Nepal, Nepal occupies an important place in south Asian region. Nepal is not only placed at the crossroads of two most powerful civilization but also in the heart of Himalayas, the formidable range of mountains separating Indo-sub-continent from the Tibet-Chinese region. Nepal occupies the central position in the Himalayan and control about $1 / 3^{\text {rd }}$ of the mountain range (P.R, 1991). The concern of national security began to evolve during the period of unification by late king Prithivi Narayan Shah. Basically, the security issues came to surface because of the threat posed by East India company during $18^{\text {th }}$ and $19^{\text {th }}$ century. The security perception that evolved at that time did not change even with the passage of successive regimes even after India became independent from British colonization and the birth of China as a people's republic after communist party (Bhattarai , 2013).

Basically, a nation has two types of national interest which are primary national interest and secondary national interest. Primary interest is the protection of the country's territory, sovereignty and independence. Secondary national interest can be understood as the interest of people, protection of property and prosperity of the people (Ghos, 2013). Nepal has been facing critical challenges brought on by a trade deficit. Similarly, connectivity partners must remain sensitive to secondary national interest and address it before its problem turn it into a primary national interest that could bring threat of sovereignty and territorial integrity. The conventional security approaches applied exclusively to the military threat. Nowadays, key security challenges are environmental, socio-cultural, technological, and other challenges. New 
power competition among nations doesn't focus on direct territorial control but on informal influence.

Economic power is the major priority of a developed nation. Geo-economics is mainly geo-strategic use of economic power. Geoeconomics proceeds from the assumption that power and security are not simply coupled to the physical control of territory, but also to commanding and manipulating the economic ties that bind states together (Scholvin \& Mikael, 2018). In June 2020, the border tension between China and India almost generated an obligatory environment for the South Asian countries to take a side (Zheng, 2020). India is speculative about Nepal's neutrality alluding China's growing interest in Nepal (Gupta, 2020). Nepal's recurrent calls to resolve border issue between China and India are overlooked by New Delhi (Republica, 2020). Nepal's foreign policy of neutrality and non-alignment in dealing with Sino-Indian disputes is understood by the foreign policy experts as Nepal's survival strategy. But, if India \& China become friend, will Nepal lose the strategic space (Muni, 2016).

The growing nexus between various armed groups in Nepal and India, human trafficking and uncontrollable migratory movements are the issues that India and Nepal have recognized as the newer threats to the security as well as interests of both countries. India is persistently requesting Nepal to control the illegal activities of alleged Pakistan intelligence supported group activities in Nepal's land. The security concern of India has grown much higher after the northern border has become sensitive due to concern along China.
China is also concerned about Nepal, if Nepal will be used by other powers to challenge its strategic interests. China security experts argues that country is being used by United States of America in its larger strategy of encircling China. In the land of Nepal, several demonstrations for Tibetan separatists have been taking place, which led China to be skeptical on external engagement in the country (Dabhade \& Pant, 2004).

\section{Connectivity Impacts in Other Countries}

\section{Case from LAO (PDR)}

Lao People's Democratic Republic (PDR) is landlocked country which used to be viewed as fated to grow less rapidly than its neighboring countries. But, with the development of GMS corridors, LAO finds itself as an epicenter connecting 600 million people from ASEAN with PRC population of 1.3 billion and $\$ 7$ trillion economy. However, not all the impacts are positive. Due to the agreement between those countries, truck industry of LAO is suffering because preinspected fruit from Thailand is transported cross-border to China freely \& uninterruptedly without being loaded into Lao PDR trucks. Fortunately, Lao PDR has plenty to offer, in tourism and regional commerce sector. Data shows that tourist visitors in the Indo China region now include Lao PDR in their itineraries. Furthermore, European tourist also choose Lao PDR to visit through bridge in Vientiane than using International Airport (WiriyaPong, 2013).

\section{Case from India}

The South Asian association for regional cooperation (SAARC), regional multimodal transport study has determined priority corridors in India which include 7 out of 10 road corridors for SAARC trade. The 
connectivity in Siliguri corridor (informally referred to as the chicken's neck) to in West Bengal connecting SASEC (South Asian Sub Regional Economic Cooperation) countries, is critical to expanding intercountry trade in South Asia. This corridor links India's North Bengal and Northeastern region, Bhutan, and Nepal with the ports in Bangladesh and India. The Bay of Bengal initiative for multisector Technical and Economic Cooperation (BIMSTEC) Transport Infrastructure and Logistics study highlights the importance of road connectivity of India with the neighboring countries. Similarly, government of India provides substantial investment in the National Highway Development project for in-country connectivity, and additional investment in the last mile connectivity extending from in country trunk road network to strengthen both Intra-SASEC and SASECMyanmar connectivity (ADB, 2018). Pant, 2008 considers economic progress in NER (Northeast Region) of India as one of the major determinants of India's relation with its neighboring countries and bearing of these relations on the country's security concern. The formation of mini-golden quadrilateral for the NER and substantive developments in the road, railway, water, air and telecommunication networks, beside increased linkage to New Delhi would allay fears stemming from the geographic constraint of the Chicken's neck.

The ambitious plan launched by China in 2014 to connect China with its neighboring countries involving more than 60 countries to finance OBOR projects through Asian Infrastructure Investment Bank (AIIB) and the $\$ 40$ billion silk road fund. India has persistent security concern which includes unresolved border dispute with China, the psychological baggage of 1962 war, the frequent incursion by Chinese armed forces into Indian territory. Furthermore, China's close tie with Pakistan and the power rivalry between India and China have created a state of lack of trust between two countries. The India perceives security threat and become cautious about any project proposed by Beijing that involves Pakistan or other neighboring countries (House, 2015).

\section{Case from Bhutan}

The ambitious sub regional road connectivity plan of India involving Bangladesh, Bhutan, India, and Nepal (BBIN) ${ }^{2}$ is blocked, as Bhutan withdrew the agreement. These four countries had signed the motor vehicle agreement aimed at allowing seamless movement of passenger and Cargo vehicles through each other's territory at Thimphu in June 2015. However, all the nation needed to ratify the pact from parliament to be operational. So far only India, Bangladesh \& Nepal have done so. This connectivity was coupled with the strategic India-MyanmarThailand trilateral highway, which links India to Myanmar and then further to southeast Asia (Mukherjee, 2015).

The southern East West highway between the towns of Dewathang and Nganglam, which is one of the main crossing points between Bhutan and India improved the connection between Bhutan's main north south highway and India's national highway network. As a result, travel time decreased by $80 \%$ from 12 hours to few hrs. The projects have made Bhutan more competitive in terms of international trade and spread the benefit of cross border commerce with its regional neighbors to people across the country,

2 BBIN: Bangladesh, Bhutan, India, Nepal (BBIN) is a subregional architecture of countries in eastern South Asia to formulate, implement and review agreement in water resource, power, transport and infrastructure. 
including the poorest and most disadvantaged (ADB, 2017).

\section{Case from Pakistan}

The CPEC (China Pakistan Economic Corridor) is an important part of (OBOR) road, which is regarded as a major change that promises to bring peace and prosperity to Pakistan. The main purpose is to upgrade and expand Pakistani's infrastructure, linking China's western province of Kashgar with Pakistan's Gwadar port on the Indian ocean. With the implementation of CPEC project, the Pakistan's can reduce its poverty and improve living standard of people.

However, Pakistan faces severe challenges and impediments to achieve the maximum benefit of CPEC, including economic instability, especially in Baluchistan, terrorism \& religious violence, security threats, convergent interests, geographical circumstances, and other external challenges. Some people with undue interests have opposed CPEC project with the exaggerative apprehensions about security situation in Gwadar. Both China and Pakistan have internal security threats and Pakistan suffers more from extremism and terrorism. From Xinjiang to Gwadar, there are many extremist groups, consisting of Tehreeke-Taliban Pakistan (TTP), East Turkestan Islamic movement (ETIM), Tehreek-eTaliban Pakistan (TTP), Daesh, Balochistan Liberation Front and the Militant wings of some political parties (Ahmad, Mi, \& Fernald, 2020).

\section{Conclusion}

It is necessary to correlate North South connectivity with economic aspect and security concern of nation. The qualitative strategy using secondary sources like journal articles, conference proceedings, books, government reports, newspaper, interviews and limiting our study area to road connectivity projects, it is found that connectivity issues are highly sensitive and can have both positive and negative impacts. Basically, the evidence from other countries case studies reveal that it is necessary to plan large scale projects with different dimensions like security, economy, international relation, political balance etc. The geo-strategic location of Nepal between two giant nations India and China creates both opportunity and threat for Nepal. Two rapidly growing economy connected through the path of Nepal can maximize economic competency of Nepal. Basically, instead of relying on road connectivity, multimodal transportation connectivity with rail, waterway should be developed. However, lessons should be learned from LAO (PDR) so that local resources and manpower can be utilized and mobilized for the prosperity of Nepalese people. The enhanced regional connectivity can improve the employment status of country, thus controlling the migration of skilled and unskilled labor to third countries in search of the jobs. Similarly, tourism industry, transportation industry and hotel industry can be flourished creating ample contributions in GDP (Gross Domestic Product) of country. But the government should be cautious while doing trade agreement and should maintain its relationship with neighbors, regional power, and great power based on sovereign equality, mutual respect, and mutual benefits. While accepting soft loans, technical support, or other loans from Exim banks for financing large scale strategic projects, Nepal should implement it by avoiding the possibility of being a debt trap victim. On the other hand, while accepting proposal of one country, Nepal should assure other 
countries that Nepal is neutral in terms of alignment and the engagement is purely for its economic interest. Small states like Nepal need to create more focus in international relations and achieve goals by promoting a positive reputation and image abroad while adopting principle of neutrality and utilizing its potential based on national interest and priority of nation. It is necessary to develop consensus among leaders as well as people to develop common opinion and utilize the international assistance and support in the development endeavors of country. Both BRI and MCC projects which are based on regional connectivity should be utilized in the favor of nation while maintaining sovereignty, independence, and mutual respect between nations.

\section{References}

ADB. (2017). Bhutan: South Asia Subregional Economic Cooperation Road Connectivity Project. Thimphu: Asian Development Bank.

ADB. (2018). Sector Assessment: Regional Road Transport. Delhi: Asian Development Bank.

ADB. (2019). Sector Assessment Transport (Road). South Asia Subregional Economic Cooperation Highway Improvement Project.

Ahmad, R., Mi, H., \& Fernald, L. (2020). Revisiting the potential security threats linked with the China-Pakistan Economic Corridor (CPEC). Journal of the International Council for Small Business.

Andersen, H. (2015, June 13). The North-South Corridors: Roads to Local Prosperity. Local Nepal Today.

Arvis, J., Raballand, G., \& Marteau, J. (2011). Connecting landlocked Developing Countries to Market: Trade corridor in the 21st century. Washington DC: World Bank.
Baniya, D. (2020). Geo-Strategic Importance of Nepal. Unity Journal, 54-70.

Bhattarai, B. (2003). The Nature of Underdeveloped and Regional Structure of Nepal: A Marxist Analysis. New Delhi: Adroit Publishers.

Bhattarai, R. (2013). Corporative Security in South Asia and Nepal's Security Concerns. In N. Nayaks, Cooperative Security Framework for South Asia (p. 116). New Delhi: Pentagon Press.

Dabhade, M., \& Pant, H. (2004). Coping with Challenges to Soverignry: Sino-Indian rivalry and Nepal's foreign policy. Contemporary South Asia, 13(2), 157-169.

Ghos, P. (2013). International Relation. Delhi : Learning Pvt Ltd.

Gupta, S. (2020, June 10). In Nepal's map tactics, a reflection of China's growing foot print in Kathmandu. Hindustan Times.

Hayashi, T., Das, S., Khadka, M., Isonoi, I., Keola, S., Tsubota, K., \& Hayakaw, K. (2020). Economic Impact Analysis of Improved Connectivity in Nepal. ADB South Asia Working Paper Series no. 75.

Gateway House (2015, May 14). OBOR and India's Security Concerns. https://www. gatewayhouse.in/security-implications-ofchinas-transnational-corridors/

IOM. (2019). Migration in Nepal. Kathmandu: IOM Development Fund.

IPCS. (n.d.) Institute of Peace and Conflict Studies: http://www.ipcs.org/

Kumagai, S., \& Isono. (2011). Economic Impacts of Enhanced ASEAN-India Connectivity: Simulation Results from IDE/ERIA-GSM. The Comprehensive Asia Development Plan, Phase II. 
Mukherjee, S. (2015, June 1). Sub-regional road connectivity Pacts: From 'looking East' to linking East. Indian Express. https:// indianexpress.com/article/india/india-others/ sub-regional-road-connectivity-pacts-fromlooking-east-to-linking-east/

Muni, S. (2016). Trilateral Engagement between India, China and Nepal; India-ChinaNepal:Decoding Trilateralism. New Delhi.

P.R, U. (1991). Nepal and South Asian Regional Security. CNAS Journal, 19-28.

Pant, M. (2008). Connectivity Issues in India's Neighbourhood. Asian Institute of Transport Development.

Paul, S., Ansu, T., \& Sharma, S. (2013). Building Roads and Improving Livelihoods in Nepal. Swiss Agency for Development and Cooperation (SDC).
Rana, P., \& B, K. (2014). A Connectivity Driven Development Strategy for Nepal: From a Landlocked to Landlinked State. Asian Development Bank Institute.

Republica. (2020, june 15). India continuously ignoring Nepal's call for holding talks to resolve border issues. Republica.

Scholvin, S., \& Mikael, W. (2018). Power Politics by Economic Means: Geo-economics as an analytical approach and foreign policy practices. Comparative Strategy.

Singh, S. (2019, April 23). Belt and Road Initiative: Nepal's Concern and Committment. The Himalayan Times.

Thapa, G. (2020, July 25). Nepal's Geographical Dilemma. East Asia Forum.

Tsang, F., \& Rohr, C. (2011). The Impact of Migration on Transport and Congestion. Santa Monica: Rand Corporation.

WiriyaPong, N. (2013, July 1). Connecting with LAOS. The Bangkok Post.

Zheng, S. (2020). China-India border dispute may force South Asian neighbours to pick a side. South China Morning Post. 